\title{
PELATIHAN PEMANFAATAN MEDIA SOSIAL SEBAGAI ALAT PEMASARAN BAGI UMKM DI KECAMATAN KEDUNGPRING, KABUPATEN LAMONGAN, JAWA TIMUR
}

\section{(TRAINING ON THE USE OF SOCIAL MEDIA AS A MARKETING FOR UMKM IN KEDUNGPRING LAMONGAN EAST JAVA)}

\author{
Maurisia Putri Permatasari ${ }^{1}$, Annysa Endriastuti ${ }^{2}$ \\ ${ }^{1}$ Prodi Manajemen Pemasaran, ${ }^{2}$ Prodi Bahasa Inggris Fakultas Vokasi, Universitas \\ Airlangga \\ e-mail: maurisiaputri@vokasi.unair.ac.id
}

\begin{abstract}
This community service aims to give some solutions for marketing problems of UMKM in Kecamatan Kedungpring, Kabupaten Lamongan, Jawa Timur. Partners face issues related to promotions, especially promotions through social media. Therefore, training about online marketing is given to partners. Partners are able to practice online marketing well, also improve online marketing techniques knowledge indicated by pre-test and post-test given by team.
\end{abstract}

Keywords: online marketing, promotion, social media

\begin{abstract}
abstrak
Pengabdian masyarakat melalui program PKM ini bertujuan untuk membantu memberikan solusi bagi persoalan yang dihadapi mitra, dalam hal ini persoalan pemasaran untuk menambah omzet UMKM di Kecamatan Kedungpring, Kabupaten Lamongan, Jawa Timur. Solusi yang ditawarkan dalam bentuk pelatihan pemasaran online melalui media sosial. Indikator keberhasilan dalam program ini adalah mitra yang dilatih mampu menjelaskan pemasaran online melalui media sosial dengan baik. Pelatihan terkait teknik-teknik berpromosi melalui media sosial juga akan dilakukan agar pengetahuan mitra semakin bertambah. Selain itu disediakan lembar kerja untuk memonitor aktivitas mitra dan mengukur efektivitas penyampaian materi dari tim kepada mitra. Luaran dari program ini adalah artikel yang dipublikasikan di jurnal nasional atau prosiding.
\end{abstract}

Kata kunci: media social, pemasaran online, promosi

\section{PENDAHULUAN}

Perkembangan pemasaran di era digital mengalami perubahan yang cukup signifikan, terutama terkait alat pemasaran yang digunakan, salah satunya dengan penggunaan media online. Pertumbuhan penjualan online dipacu oleh semakin berkembangnya teknologi handphone, tablet, dan media social (Internet Retailer 2012). Dalam jangka panjang, pemasaran melalui internet dan peningkatan penjualan melalui e-commerce diperkirakan melampaui penjualan melalui saluran tradisional (Pomirleanu et al 2013).

Pemasaran, termasuk iklan, didesain untuk memberitahu konsumen seperti apa produk mereka, bagaimana produk tersebut dapat memuaskan kebutuhan konsumen, dan bagaimana konsumen dapat memesan (Mcclurg 2013). Maka, pemahaman iklan oleh pelaku bisnis sangat penting agar pesan yang disampaikan dalam iklan tersebut dapat sampai ke pikiran konsumen dengan tepat. 
Menurut Magrath dan McCormick (2013), penjual online dapat menyampaikan secara visual merk, kepribadian, dan identitas produk melalui rangsangan desain visual. Dengan melakukan hal tersebut, mereka mampu meberi dampak pada respon emosional konsumen, perilaku, reaksi dan pengalam hedonis (Kim and Lennon 2010).

Kecamatan Kedungpring merupakan salah satu kecamatan di Kabupaten Lamongan yang memiliki UMKM binaan yang memproduksi produk olahan makanan. Pada dasarnya, mitra membentuk bisnis berdasarkan pada produk unggulan daerah, antara lain jagung dan ikan. Hal ini selaras dengan salah satu agenda dalam program Presiden Joko Widodo dalam Nawacita adalah mewujudkan kemandirian ekonomi dengan menggerakkan sektor strategis ekonomi domestik, dengan sub agenda peningkatan kedaulatan pangan yang salah satu sasarannya yaitu "Pengembangan 1000 Desa Pertanian Organik" dengan pembagian target sebagai berikut; 1) Direktorat Jenderal Tanaman Pangan 600 desa, 2) Direktorat Jenderal Hortikultura 250 desa, dan 3) Direktorat Jenderal Perkebunan 150 desa (http://tanamanpangan.pertanian.go.id/ ,diakses 20 Februari 2018).

Penerapan manajemen bisnis pada kedua mitra dirasa sudah cukup baik, digambarkan dengan pemilihan produk yang tepat dan pemanfaatan hasil panen diolah supaya lebih bernilai jual. Bahan baku diambil dari hasil tanaman pangan lokal yang diolah secara organik. Harga yang ditetapkan juga terjangkau, mengingat bahan yang digunakan berkualitas baik. Penentuan harga didasarkan pada ongkos produksi dan disesuaikan dengan kemampuan pasar. Para mitra menyadari bahwa_harga merupakan salah satu atribut utama dalam keputusan pembelian (Mai and Hoffman 2012). Green product seperti halnya produk organik biasanya dianggap lebih mahal dibanding barang konvensional (Aslihan Nasir and Karakaya 2014). Konsumen menyatakan bahwa harga yang tinggi merupakan hambatan untuk konsumsi produk ramah lingkungan (Paul and Rana 2012), maka para mitra memilih menerapkan harga yang sesuai dengan daya beli konsumen.

Proses produksi yang selama ini dilakukan oleh mitra sudah cukup baik. Olahan-olahan dibuat dengan higienis dan diberi sentuhan inovasi agar produk yang dijual tidak membosankan dan memiliki daya tarik. Para anggota juga telah memahami pentingnya mengurus ijin usaha, termasuk perijinan p-IRT dan logo halal. Mitra juga aktif mengikuti pameran-pameran di berbagai kota sebagai upaya untuk memperkenalkan produknya. Masing-masing anggota biasanya memproduksi secara individu untuk produk-produk keripik dan kemudian dibawa ke rumah ketua kelompok untuk dikemas dan diberi label. Menurut Moser (2015), pemasar diharapkan mampu memperhatikan alasan yang mempengaruhi pembelian konsumen. Maka, beberapa contoh produk didisplay dan disisihkan untuk sample test tanggal kedaluarsa.

Berdasarkan analisis situasi yang telah digambarkan serta hasil diskusi tim pengusul dengan mitra, dapat disimpulkan beberapa permasalahan yang dihadapi oleh mitra: 1) Pemasaran yang dilakukan kedua mitra sejauh ini hanya mengandalkan pada pameran serta pesanan dari penduduk lokal, belum memiliki rencana dan pemahaman pemasaran secara komprehensif dan efektif; 2) Kurangnya pengetahuan mitra dalam memasarkan produk secara online serta manfaatnya. Pemanfaatan akun media social merupakan masalah prioritas yang dihadapi mitra. Pemasaran online sangat membantu untuk 
mempromosikan produk agar menjangkau daerah yang lebih luas dan pasar sasaran yang sesuai.

Beberapa permasalahan mitra tersebut ditindaklanjuti oleh tim pelaksana dengan langkah: 1) Mengadakan penyuluhan mengenai pemasaran terutama komponen promosi. Penyuluhan yang diberikan meliputi media-media promosi yang dapat digunakan, pemilihan media promosi yang tepat, contoh-contoh media promosi yang dapat digunakan oleh mitra; 2) Mengadakan penyuluhan dan pelatihan mengenai akun media social sebagai sarana melakukan promosi. Penyuluhan diberikan sebagai dasar pemberian informasi mengenai fungsi media social sebagai alat promosi. Pelatihan diberikan dengan cara tutorial membuat akun media social untuk bisnis dengan konten yang benar dan menarik; 3) Pada tahap evaluasi diberikan pre-test dan post-test mengenai pengetahuan tentang akun media sosial.

\section{METODE PENGABDIAN MASYARAKAT}

Solusi yang ditawarkan kepada mitra dalam pelaksanaan pengabdian kepada masyarakat bersama tim untuk mengatasi permasalahan yang berhubungan dengan pemasaran produk adalah penyuluhan mengenai pemasaran terutama komponen promosi. Selain itu juga diadakan penyuluhan dan pelatihan mengenai akun media social sebagai sarana melakukan promosi.

Survei dilakukan saat akan melaksanakan kegiatan. Survei tempat dilakukan di Kecamatan Kedungpring, Kabupaten Lamongan. Hasil survey tersebut dijadikan acuan dalam memberikan materi pelatihan yang tepat serta sebagai dasar penyusunan pertanyaan pre-test dan post-test.

Pelatihan dilakukan dengan menggunakan metode tutorial dan visualisasi. Materi yang diberikan meliputi pemasaran yang efektif, strategi promosi online, dan cara membuat konten media social yang menarik dan menimbulkan minat beli konsumen.

Dalam pelatihan yang dilakukan tim pengusul, mitra berpartisipasi dalam hal penyediaan tempat dan peserta pelatihan media pemasaran online. Selain itu, mitra memberikan evaluasi pelaksanaan pelatihan sebagai masukan untuk tim pengusul.

\section{HASIL DAN PEMBAHASAN}

\section{Pretest}

Sebelum pelatihan dimulai, diadakan pretest oleh tim sebagai salah satu cara megukur pengetahuan mitra mengenai pemasaran dan sosial media sebelum diberi pelatihan. Mitra diminta menjawab beberapa pertanyaan yang telah disiapkan oleh tim. Pertanyaan-pertanyaan tersebut bersifat terbuka, artinya mitra bebas mendeskripsikan jawabannya tanpa dibatasi beberapa pilihan-pilihan jawaban.

Pertanyaan pertama yang diajukan oleh tim kepada mitra adalah sebutkan salah satu media sosial yang anda ketahui. Jawaban mitra dapat dilihat pada tabel berikut: 
Tabel 1. Media sosial yang diketahui mitra

\begin{tabular}{cccc}
\hline No & Jawaban & Jumlah & Persentase \\
\hline 1 & Facebook & 23 & $38,33 \%$ \\
2 & Instagram & 8 & $13,33 \%$ \\
3 & Twitter & 6 & $10 \%$ \\
4 & WhatsApp & 15 & $25 \%$ \\
5 & Tidak tahu & 8 & $13,33 \%$ \\
\hline
\end{tabular}

Sumber: data diolah, 2018

Tabel 1. menunjukkan bahwa sebesar 38,33\% mitra menjawab facebook, 13,33\% mitra menjawab instagram, $10 \%$ mitra menjawab twitter, $25 \%$ mitra menjawab whatsapp, dan sebesar 13,33\% mitra menjawab tidak tahu. Hal ini menunjukkan bahwa beberapa mitra masih belum mengenali jenis-jenis media sosial yang dapat digunakan sebagai alat pemasaran.

Pertanyaan kedua yang diajukan oleh tim kepada mitra adalah sebutkan salah satu media sosial yang sudah anda gunakan untuk membantu dalam memasarkan produk

Tabel 2. Media sosial yang sudah digunakan mitra

\begin{tabular}{cccc}
\hline No & Jawaban & Jumlah & Persentase \\
\hline 1 & Facebook & 20 & $33,33 \%$ \\
2 & Instagram & 5 & $8,33 \%$ \\
3 & Twitter & 4 & $6,67 \%$ \\
4 & WhatsApp & 15 & $25 \%$ \\
5 & Tidak ada & 16 & $26,67 \%$ \\
\hline
\end{tabular}

Sumber: data diolah, 2018

Tabel 2. menunjukkan bahwa sebesar 33,33\% mitra menjawab facebook, 8,33\% mitra menjawab instagram, 6,67\% mitra menjawab twitter, $25 \%$ mitra menjawab whatsapp, dan sebesar 26,67\% mitra menjawab tidak tahu. Hal ini menunjukkan beberapa mitra belum menggunakan jenis-jenis media sosial yang dapat digunakan sebagai alat pemasaran.

Pertanyaan ketiga yang diajukan oleh tim kepada mitra adalah sebutkan salah satu hal penting yang harus ada dalam media sosial yang digunakan untuk membantu memasarkan produk. Jawaban mitra dapat dilihat pada tabel berikut:

Tabel 3. Hal penting yang harus ada dalam media sosial

\begin{tabular}{cccc}
\hline No & Jawaban & Jumlah & Persentase \\
\hline 1 & Kemasan produk & 12 & $20 \%$ \\
2 & Kualitas produk & 15 & $25 \%$ \\
3 & Foto & 10 & $16,67 \%$ \\
4 & Bahasa & 10 & $16,67 \%$ \\
5 & Profil usaha & 5 & $8,33 \%$ \\
6 & Tidak tahu & 8 & $13,33 \%$ \\
\hline
\end{tabular}


Sumber: data diolah, 2018

Tabel 1.3 menunjukkan bahwa sebesar $20 \%$ mitra menjawab kemasan produk, $25 \%$ mitra menjawab kualitas produk, 16,67\% mitra menjawab foto, 16,67\% mitra menjawab bahasa, dan sebesar $8,33 \%$ mitra menjawab profil usaha, dan 13,33\% mitra menjawab tidak tahu. Hal ini menunjukkan bahwa beberapa mitra masih belum mengetahui dengan tepat hal-hal apa saja yang pemting dan harus ada dalam media sosial yang dapat digunakan sebagai alat pemasaran.

\section{Pelatihan Pemanfaatan Akun Media Sosial}

Permasalahan yang dihadapi mitra di Kecamatan Kedungpring mengenai promosi secara online merupakan target utama dalam program pengabdian kepada masyarakat ini. Pada tahap pertama tim memberikan beberapa materi mengenai media sosial terkait dengan pemasaran produk. Media sosial merupakan salah satu alat pemasaran yang efektif saat ini karena sebagian besar masyarakat telah menggunakan berbagai macam media sosial. Beberapa contoh media sosial yang banyak digunakan adalah Facebook, Instagram, Twitter, serta Pinterest. Masing-masing media sosial tersebut memiliki ciri khas serta kelebihan dan kekurangan masing-masing.

Facebook merupakan media sosial yang paling populer digunakan, terutama oleh masyarakat Indonesia. Hal yang sebaiknya ditampilkan di Facebook sebagai sarana promosi adalah gambar beserta keterangan yang menyertainya. Link berita juga dapat dicantumkan sebagai pelengkap dalam usaha menarik minat konsumen pada produk yang ditampilkan. Promosi melalui Facebook dapat menjangkau pasar sasaran dengan lebih luas, mencakup berbagai rentang usia serta wilayah tempat tinggal.

Bagi pelaku bisnis yang memiliki keunggulan dalam hal foto produk sebagai alat promosi, maka Instagram dan Pinterest merupakan jenis media sosial yang cocok untuk digunakan. Selain itu dibantu dengan tanda pagar (hashtag) akan mempermudah pelaku bisnis untuk menjangkau pasar sasaran yang dituju. Namun pengguna instagram dan pinterest sebagian besar merupakan kalangan anak muda, sehingga perlu menampilkan foto yang benar-benar menarik disertai hashtag yang sesuai.

Twitter biasanya lebih banyak digunakan untuk membagikan tulisan, sehingga beberapa pelaku bisnis jarang menggunakan twitter sebagai sarana menampilkan produk yang dipasarkan. Diperlukan keterampilan menyusun bahasa yang tepat untuk ditampilkan pada akun Twitter jika ingin melakukan promosi produk.

Selain membahas mengenai contoh media sosial yang dapat digunakan sebagai alat pemasaran serta ketentuan penggunaannya, tim juga menyajikan informasi mengenai beberapa ketentuan yang harus ada dalam media sosial yang digunakan untuk bisnis. Ketentuan tersebut terkait dengan kualitas konten, pemilihan waktu posting dan frekuensi posting, serta tugas harian hingga bulanan yang harus dilakukan dalam mengelola akun media sosial.

\section{Posttest}

Setelah penjelasan materi oleh tim, diadakan posttest oleh tim sebagai salah satu cara megukur pengetahuan mitra mengenai pemasaran dan sosial media setelah diberi 
pelatihan. Mitra diminta menjawab beberapa pertanyaan yang telah disiapkan oleh tim. Pertanyaan-pertanyaan tersebut bersifat terbuka, artinya mitra bebas mendeskripsikan jawabannya tanpa dibatasi beberapa pilihan-pilihan jawaban.

Pertanyaan pertama yang diajukan oleh tim kepada mitra adalah sebutkan salah satu media sosial yang anda ketahui. Jawaban mitra dapat dilihat pada tabel berikut:

Tabel 4. Media mitra

\begin{tabular}{cccc}
\hline No & Jawaban & Jumlah & Persentase \\
\hline 1 & Facebook & 37 & $61,67 \%$ \\
2 & Instagram & 18 & $30 \%$ \\
3 & Twitter & 5 & $8,33 \%$ \\
\hline
\end{tabular}

sosial yang diketahui

Sumber: data diolah, 2018

Tabel 4. menunjukkan bahwa sebesar $41,67 \%$ mitra menjawab facebook, $20 \%$ mitra menjawab instagram, 33,33\% mitra menjawab twitter, 5\% mitra menjawab pinterest. Hal ini menunjukkan bahwa mitra mengenali jenis-jenis media sosial yang dapat digunakan sebagai alat pemasaran.

Pertanyaan kedua yang diajukan oleh tim kepada mitra adalah sebutkan salah satu media sosial yang akan anda gunakan sebagai alat pemasaran Jawaban mitra dapat dilihat pada tabel berikut:

Tabel 5. Media sosial yang akan digunakan mitra

\begin{tabular}{cccc}
\hline No & Jawaban & Jumlah & Persentase \\
\hline 1 & Facebook & 25 & $41,67 \%$ \\
2 & Instagram & 12 & $20 \%$ \\
3 & Twitter & 20 & $33,33 \%$ \\
4 & Pinterest & 3 & $5 \%$ \\
\hline
\end{tabular}

Sumber: data diolah, 2018

Tabel 5. menunjukkan bahwa sebesar $61,67 \%$ mitra menjawab facebook, $30 \%$ mitra menjawab instagram, dan $8,33 \%$ mitra menjawab twitter. Hal ini menunjukkan bahwa mitra telah memahami manfaat menggunakan media sosial sebagai alat pemasaran serta tertarik untuk menggunakannya sesuai dengan kebutuhan masing-masing produk yang dipasarkan oleh mitra. Beberapa mitra merupakan pelaku usaha yang belum memiliki akun media sosial untuk memasarkan produknya, setelah dilakukan pelatihan dan mendapatkan materi dari tim mengenai pemasaran online dan manfaatnya maka mitra mulai membuat rencana untuk membuat akun media sosial yang sesuai dengan kebutuhan dan keinginan mitra untuk memasarkan produk yang dimilikinya.

Pertanyaan ketiga yang diajukan oleh tim kepada mitra adalah mengapa media sosial merupakan salah satu alat pemasaran yang penting digunakan oleh pelaku usaha. Jawaban mitra dapat dilihat pada tabel berikut: 
Tabel 6. Media sosial yang diketahui mitra

\begin{tabular}{cccc}
\hline No & Jawaban & Jumlah & Persentase \\
\hline 1 & Mempermudah promosi & 2 & $3,33 \%$ \\
2 & Semua serba online & 8 & $13,33 \%$ \\
3 & Hemat tempat & 9 & $15 \%$ \\
4 & Memudahkan penjualan & 13 & $21,67 \%$ \\
5 & Menguntungkan & 8 & $13,33 \%$ \\
6 & Jangkauan luas & 15 & $25 \%$ \\
7 & Tidak perlu membayar sewa toko & 5 & $8,33 \%$ \\
\hline
\end{tabular}

Sumber: data diolah, 2018

Tabel 6. menunjukkan bahwa sebesar 3,33\% mitra menjawab mempermudah promosi, $13,33 \%$ mitra menjawab semua serba online, $15 \%$ mitra menjawab hemat tempat, $21,67 \%$ mitra menjawab memudahkan penjualan, dan sebesar $13,33 \%$ mitra menjawab menguntungkan, $25 \%$ mitra menjawab jangkauan luas, dan 8,33\% mitra menjawab tidak perlu membayar sewa toko. Hal ini menunjukkan bahwa mitra memahami pentingnya memiliki akun media sosial sebagai alat pemasaran. Jawaban yang diberikan mitra sesuai dengan materi yang disampaikan oleh tim serta sesuai dengan pembahasan yang dilakukan saat sesi diskusi dan tanya jawab antara mitra dengan tim.

Pertanyaan keempat yang diajukan oleh tim kepada mitra adalah hal penting apa saja yang harus dilakukan dalam mengelola akun media sosial sebagai alat pemasaran. Jawaban mitra dapat dilihat pada tabel berikut:

Tabel 7. Hal penting dalam mengelola akun media sosial

\begin{tabular}{cccc}
\hline No & Jawaban & Jumlah & Persentase \\
\hline 1 & Tampilan profil & 4 & $6,67 \%$ \\
2 & Foto yang menarik & 23 & $38,33 \%$ \\
3 & Postingan yang menarik & 12 & $20 \%$ \\
4 & Waktu saat memposting & 8 & $13,33 \%$ \\
5 & Kata-kata yang digunakan & 8 & 13,33 \\
\hline
\end{tabular}

Sumber: data diolah, 2018

Tabel 7. menunjukkan bahwa sebesar 6,67\% mitra menjawab tampilan profil, 38,33\% mitra menjawab foto yang menarik, $20 \%$ mitra menjawab postingan yang menarik, $13,33 \%$ mitra menjawab waktu saat memposting, dan sebesar 13,33\% mitra menjawab kata-kata yang digunakan. Hal ini menunjukkan bahwa mitra memahami materi yang diberikan oleh tim. Pembahasan yang diberikan oleh tim terkait konten dalam media sosial yang harus diperhatikan oleh mitra merupakan hal penting karena akan menentukan keberhasilan mitra dalam menarik minat konsumen untuk mengunjungi akun media sosial hingga tertarik untuk melakukan pembelian.

Hasil post-test menggambarkan peningkatan pengetahuan mitra akan pentingnya menggunakan media sosial sebagai alat pemasaran. Mitra juga menunjukkan pemahaman mengenai komponen-komponen yang harus disediakan dalam mengelola 
akun media sosial untuk bisnis. Selain itu, mulai adanya kesadaran dari mitra untuk mengelola akun media sosial sesuai dengan materi yang telah dibahas dan minat beberapa mitra yang tadinya tidak memiliki akun media sosial khusus untuk bisnis untuk mulai membuat dan mengelola akun media sosial untuk bisnis merupakan peningkatan yang signifikan mengingat dalam pre-test sebagian mitra memberikan jawaban kurang tepat bahkan menjawab tidak tahu. Hasil post-test yang diolah menunjukkan semua jawaban mitra tepat dan tidak ada mitra yang menjawab tidak tahu untuk semua pertanyaan yang diberikan oleh tim.

\section{Diskusi dan Tanya Jawab}

Dalam forum diskusi dan tanya jawab, mitra nampak sangat antusias untuk membicarakan mengenai seluk beluk pemasaran melalui media social dan permasalahan lain yang sering muncul dalam melakukan pemasaran. Forum diskusi dan tanya jawab merupakan sesi paling panjang dalam program pengabdian masyarakat karena hampir setiap peserta yang hadir memiliki pertanyaan terkait pemasaran usaha yang ingin didiskusikan dengan tim pelaksana.

Pertanyaan yang banyak diajukan terkait dengan hal-hal praktis yang sering muncul dan dihadapi oleh mitra. Pertanyaan yang muncul antara lain mengenai cara untuk menjadi penjual yang terpercaya secara online, inovasi produk yang mampu diserap pasar, penggunaan bahasa yang baik dan benar untuk dicantumkan dalam akun media sosial, ketentuan dan syarat untuk berjualan di marketplace seperti shopee dan tokopedia, partner pengiriman, dan beberapa permasalahan metode pembayaran. Tim pelaksana menjawab satu persatu pertanyaan dari para peserta dan mengajak berdiskusi peserta lain untuk memberikan solusi yang terbaik.

Sesi diskusi dan tanya jawab sekaligus memberikan feedback dan evaluasi untuk tim pelaksana dan mitra. Masukan yang diberikan mitra terkait dengan pelatihan lanjutan yang dibutuhkan mengenai fungsi pemasaran yang lain, diantaranya penetapan harga dan pengembangan produk yang dibutuhkan oleh para mitra. Secara keseluruham, para mitra merasa senang dan puas dengan pelatihan yang diberikan dan merasa mendapat banyak manfaat dari sesi diskusi dan tanya jawab.

\section{PENUTUP}

\section{Simpulan}

Selama proses kegiatan pengabdian masyarakat yang telah dilakukan, sebagian besar kegiatan berjalan lancar dan baik. Mitra mampu bekerja sama dengan baik dan merasa puas akan pelatihan yang diberikan oleh tim pelaksana. Beberapa yang menjadi program mitra selanjutnya adalah menindaklanjuti saran yang diberikan oleh tim pelaksana dan merencanakan penyelarasan konten akun media social yang sudah ada. Akun media social yang masih tergabung dengan akun pribadi direncanakan akan dipindahkan ke akun baru khusus bisnis.

\section{Saran}

Saran yang dapat diusulkan oleh tim pelaksana adalah sebagai berikut: 1) Perlu adanya pelatihan lanjutan terkait pengembangan produk; 2) Perlu adanya pengarahan dari tim teknologi informasi terkait beberapa jenis aplikasi yang membutuhkan penanganan khusus dari ahli dibidangnya; 3) Berkaitan dengan hasil diskusi dengan mitra, perlu 
adanya evaluasi lanjutan mengenai konten yang telah disesuaikan setelah pelatihan untuk beberapa waktu tertentu.

\section{DAFTAR PUSTAKA}

Aslihan, Nasir V., \& Karakaya, F., 2014. "Consumer Segments in Organic Foods Market”, Journal of Consumer Marketing, Vol 31 No. 4, pp. 263-277

Internet Retailer, 2012, "E-retail spending to increase $62 \%$ by 2016 ", available at: www.internetretailer.com/2012/02/27/e-retail-spending-increase-45-2016 (accessed January 2,2017)

Kim, H. and Lennon, S., 2010, "E-atmosphere, emotional, cognitive, and behavioral responses", Journal of Fashion Marketing and Management, Vol. 14 No. 3, pp. 412-38.

Magrath, V dan McCormick, H., 2013, "Marketing design elements of mobile fashion retail apps", Journal of Fashion Marketing and Management: An International Journal, Vol. 17 Issue: 1, pp.115-134

Mai, R., \& Hoffmann, S., 2012. "Taste Lovers versus Nutrition Fact Seekers: how Health Consciousness and Self-Efficacy Determine the Way Consumer Choose Food Products", Journal of Consumer Behavior, Vol.11 No. 4, pp 316-328

Mcclurg, Robert, 2013, "Digital Marketing Is Key to Practice Growth: Making sense of SEO, PPC, DIY, DID, and Social Networking". Family Advocate, Vol. 35, No. 3 (Winter 2013), pp. 28-30

Moser, Andrea K., 2015. "Thinking Green, Buying Green? Drivers of ProEnvironmental Purchasing Behavior", Journal of Consumer Marketing, Vol.32 Iss 3, pp.167-175

Pomirleanu, N, Schibrowsky, J.A, Peltier, J., dan Nill, A, 2013. "A review of internet marketing research over the past 20 years and future research direction", Journal of Research in Interactive Marketing, Vol. 7 Issue: 3, pp.166-181

http://tanamanpangan.pertanian.go.id/berita/95, diakses $7 \quad$ Februari 2018 